JPDNISSN 2579-6461 (Online) ISSN 2460-6324 (Print)

Jurnal Pendidikan Dasar Nusantara

Volume 6| Nomor $1 \mid$ Juli 2020|

DOI:https://doi.org/10.29407/jpdn.v6i1.14439

\title{
IMPLEMENTASI KEDISIPLINAN DI SDN SUKORAME 2 SEBAGAI BEKAL MEMBENTUK PENDIDIKAN KARAKTER PADA SISWA
}

\author{
Sindy Kartika ${ }^{1}$, Frans Aditia Wiguna ${ }^{2}$ \\ Sndkartika@gmail.com ${ }^{1}$, frans@unpkediri.ac.id ${ }^{2}$ \\ PGSD, FKIP, UN PGRI Kediri ${ }^{1}$
}

\begin{abstract}
Abstrak:
SDN Sukorame 2 memiliki komitmen yang kuat untuk mengembangkan karakter pada siswa. Penelitian ini bertujuan untuk memaparkan implementasi kedisiplinan sebagai bekal membentuk pendidikan karakter pada siswa di SDN Sukorame 2. Penelitian ini menggunakan pendekatan kualitatif. Berdasarkan hasil penelitian bahwa implementasi kedisiplinan sebagai bekal membentuk pendidikan karakter pada siswa di SDN Sukorame 2 telah dicurahkan kedalam program sekolah yang meliputi: Siswa hadir 10 menit sebelum pelajaran dimulai, siswa memakai seragam sesuai jadwal, mengikuti upacara benderan dengan khidmat, melaksanakan dan mentaati tata tertib sekolah, melaksanakan tugas piket sesuai jadwal.
\end{abstract}

Kata kunci: Implementasi kedisiplinan. Pendidikan karakter

\section{IMPLEMENTATION OF DISCIPLINE IN SDN SUKORAME 2 AS A PROVISION TO SHAPE CHARACTER EDUCATION FOR STUDENT}

\begin{abstract}
:
SDN Sukorame 2 has a strong commitment to develop student character. This study aims to explain the implementation of discipline as a provision to shape character education for students at SDN Sukorame 2. This study uses a qualitative approach. Based on the results of the study that the implementation of discipline as a provision to shape character education in students at SDN Sukorame 2 has been poured into the school program which includes: Students present 10 minutes before the lesson begins, students wear uniforms according to schedule, attend a ceremony with a solemn ceremony, carry out and obey the rules school, carry out picket duties according to schedule.
\end{abstract}

Keywords: Implementation of discipline. character building 
Sindy,Frans.Implementasi Kedisiplinan di SDN Sukorame 2.....

\section{PENDAHULUAN}

Sikap kedisiplinan merupakan sikap yang harus ditanamkan oleh setiap siswa untuk berproses dalam dunia pendidikan. Dengan sikap disiplin dapat membantu siswa dalam menghadapi dunia pendidikan, sebagai tombak untuk pembentukan perilaku dan sikap seseorang dalam meraih kesuksesan. Fungsi kedisiplinan antara lain, (Tu’u, 2004) yaitu: menata kehidupan bersama, Fungsi kedisiplinan dapat membantu seseorang untuk menghargai dan mentaati peraturan yang berlaku. Dengan sikap disiplin seseorang dapat membangun hubungan dengan orang lain menjadi baik seperti halnya bekerjasama dalam menggunakan waktu disekitar lingkungannya . Disiplin yang diterapkan di masingmasing lingkungan tersebur memberi dampak bagi pertumbuhan kepribadian yang baik. Dngan bersikap disiplin seseorang akan terbiasa mengikuti, mematuhi aturan atau tata tertib yang berlaku dan kebiasaan itu lama-kelamaan akan membiasakan dirinya dalam membangun kepribadian yang baik.

Kualitas pendidikan dapat diketahui dari kedisiplinan setiap individu atau siswa baik dalam lingkungan sekolahnya maupun lingkungan bermasyarakat. Belajar berdisiplin merupakan salah satu faktor yang dapat meningkatkan kualitas sumber daya manusia. Berdasarkan paparan hasil observasi tanggal 27 Januari 2020 sampai tanggal 13 Maret 2020 diperoleh informasi bahwa terdapat beberapa permasalahan yang mempengaruhi proses pendidikan karakter anak adalah pada kegiatan sehari-hari mereka. Contoh permasalahan seperti ada siswa datang terlambat atau tidak mematuhi tata tertib sekolah, siswa akan diberikan sanksi yang dapat menanamkan kedisiplinan dan memberikan bekal pendidikan karakter pada siswa seperti menyayikan lagu wajib, menghafalkan UUD 1945 Secara tidak langsung sanksi yang diberikan kepada siswa dapat membentuk karakter siswa cinta tanah air.

Penelitian ini bertujuan untuk mengetahui implementasi kedisiplinan di SDN Sukorame 2 sebagai bekal membentuk pendidikan karakter pada siswa, sehingga siswa dapat disiplin waktu dan keadaan yang berada disekitarnya

Berdisiplin akan membuat seseorang memiliki kecakapan mengenai cara belajar yang baik, juga merupakan pembentukan yang baik, yang akan menciptakan suatu pribadi yang luhur. Menurut Gunarsa (2008) disiplin perlu dalam mendidik anak supaya anak dengan mudah dapat:

a. Memberitahu pengetahuan dan pengertian sosial berdasarkan lingkungannya. 
Sindy,Frans.Implementasi Kedisiplinan di SDN Sukorame 2.....

b. Memahami untuk menjalankan kewajiban dan tidak melakukan apa yang dilarang.

c. Mengetahui adanya tingkah laku baik dan buruk.

d. Belajar untuk mengendalikan keinginan dan berbuat sesuatu tanpa merasa terancam oleh hukum.

e. Mengorbankan kesenangan sendiri tanpa peringatan dari orang lain.

Kedisiplinan merupakan suatu tata tertib atau aturan untuk mengendalikan tingkah laku siswa memang harus dilakukan. Tata tertib yang disertai pengawasan akan terlaksananya dengan baik dan pemberian pengertian pada setiap pelanggaran tentunya akan menimbulkan rasa keteraturan dan disiplin diri pada diri siswa.

Fungsi pokok disiplin yaitu mengajar siswa untuk menerima pengekangan yang dilakukan dan membentuk kepribadian siswa, mengarahkan siswa ke dalam jalur yang benar dan diterima secara sosial.

\section{Fungsi disiplin yaitu:}

a. Fungsi yang bermanfaat

1) Untuk mengajarkan bahwa perilaku yang tidak disiplin akan mendapatkan sanksi atau hukuman sedangankan perilaku disiplin akan mendapatkan pujian.

2) Untuk mengajar siswa bahwa sikap displin adalah sikap yang wajar dalam menyesuaikan diri pada lingkungan sekitar.

3) Untuk membantu siswa mengendalikan diri dan pengarahan diri pada siswa.

b. Fungsi yang tidak bermanfaat

1) Untuk membuat siswa takut agar tidak melanggar peraturan.

2) Sebagai pelampiasan cara seseorang yang mendisiplin siswa.

Kedisiplinan bukan sesuatu yang terjadi secara otomatis atau spontan pada diri seseorang melainkan sikap kedisiplinan tersebut terbentuk atas dasar beberapa faktor yang mempengaruhinya. Seperti :

a. Faktor Intern (Dari dalam)

Yaitu faktor yang terdapat dalam diri orang yang bersangkutan, faktor-faktor tersebut meliputi:

1) Faktor Pembawaan : Merupakan faktor yang dibawa sejak ia lahir berdasarkan keturunan orang tuanya.

2) Faktor Kesadaran : merupakan faktor yang muncul dari dalam hati atau kesadaran seseorang untuk melakukan sesuatu yang akan dikerjakan. 
Sindy,Frans.Implementasi Kedisiplinan di SDN Sukorame 2.....

3) Faktor Minat dan Motivasi : Merupakan motivasi dan miinat dari dalam diri mereka sendiri tanpa harus menunggu adanya dorongan dari luar.

4) Faktor Pengaruh Pola Pikir : Merupakan pola pikir yang telah ada terlebih dahulu untuk melakukan suatu kehendak atau keinginan. Jika orang mulai berpikir akan pentingnya disiplin maka ia akan melakukannya.

b. Faktor Ekstern

1) Contoh dan teladan : Merupakan faktor dari orang disekitanya yaitu contoh perbuatan dan tindakan sehari-hari dari seseorang. Keteladanan merupakan salah satu teknik pendidikan yang efektif dan sukses karena dengan teladan siswa akan cenderung untuk meniru.

2) Nasihat : merupakan dorongan dari seseorang agar siswa dapat terpengaruh dengan apa yang dikatakan.

3) Faktor latihan : merupakan sikap yang dilatih sejak dini yaitu mengajarkan siswa tentang kedisiplinan yang akan membuat siswa terbiasa untuk bersikap disiplin.

4) Faktor lingkungan : merupakan lingkungan di sekolah misalnya dalam kesehariannya siswa terbiasa melakukan kegiatan yang tertib dan teratur karena lingkungan yang mendukung serta memaksanya untuk berdisiplin.

5) Faktor pengaruh kelompok : merupakan pengaruh dari orang-orang yang ada disekitar siswa yang mempunyai tujuan sama untuk berikap disiplin. Dengan Pembawaan atau latihan sangat berpengaruh dalam kedisiplinan, perubahan dari lahir yang ditunjang latihan bisa dikembangkan jika terpengaruh oleh kelompok yang berdisiplin, tetapi pembawaan yang baik ditunjang dengan latihan yang tidak baik bisa jadi tidak baik jika terpengaruh oleh suatu kelompok yang tidak baik demikian juga sebaliknya.

\section{METODE PENELITIAN}

Penelitian ini merupakan penelitian yang menggunakan pendekatan penelitian kualitatif dalam menyajikan data bersifat deskriptif yaitu yberupa kata-kata dan bahasa dalam melakukan penelitian. Penelitian ini menyajikan deskripsi tentang implementasi kedisiplinan sebagai bekal membentuk pendidikan karakter pada siswa di SDN Sukorame 2. 


\section{Sindy,Frans.Implementasi Kedisiplinan di SDN Sukorame 2.....}

Tempat penelitian ini di SDN Sukorame 2 Kota Kediri, SD tersebut telah melaksanakan kedisiplinan yang berlokasi di Jalan Himalaya No.2 telp. (0354) 777878 Kecamatan Mojoroto Kota Kediri.

Subjek penelitian ini adalah siswa SDN Sukorame 2 Sumber data dalam penelitian ini adalah hasil wawancara dengan narasumber yaitu kepala sekolah, guru serta hasil observasi implementasi kedisiplinan sebagai bekal membentuk pendidikan karakter pada siswa di SDN Sukorame 2. Sumber data selanjutnya adalah dokumen yaitu berupa dokumen tentang program SDN Sukorame 2 , serta dokumen lain yang relevan dengan penelitian ini.

Jenis data dalam penelitian kualitatif deskriptif terdiri dari dua jenis yaitu data primer dan data sekunder. Data primer dalam penelitian ini yaitu berupa hasil wawancara terhadap pihak-pihak terkait yang meliputi kepala sekolah, guru, dan siswa berkaitan dengan implementasi kedisiplinan sebagai bekal membentuk pendidikan karakter pada siswa di SDN Sukorame 2. Data sekunder merupakan data yang digunakan untuk mendukung pembahasan-pembahasan yang ada dalam penelitian ini. Adapun data sekunder meliputi dokumen-dokumen yang berupa rencana kerja sekolah, program sekolah, kurikulum sekolah, silabus, rencana pelaksanaan pembelajaran, dan foto yang berkaitan dengan implementasi kedisiplinan di SDN Sukorame 2.

Data yang diperlukan dalam penelitian ini menggunakan teknik pengumpulan data sebagai berikut: wawancara, observasi, dokumentasi. Dalam penelitian deskriptif kualitatif instrument utamanya adalah peneliti, pedoman observasi dan pedoman wawancara. Teknik analisis data dalam penelitian penelitian ini terdiri dari tiga tahap yaitu reduksi data, penyajian data dan penarikan kesimpulan, penjabaran dari ketiga tahap tersebut adalah sebagai berikut.

1. Reduksi Data (Data Reduction)

Reduksi data merupakan proses pemilahan data yang telah di kumpulkan, yaitu menyeleksi data yang sesuai dengan kebutuhan penelitian untuk di rangkum agar menemukan pola yang di harapkan. Peneliti menyeleksi dan memilah data yang berupa pandangan kepala sekolah dan guru tentang pengertian pendidikan karakter, implementasi kedisiplinan di sekolah melalui visi-misi dan program sekolah. Data yang diperoleh tersebut merupakan data yang masih kompleks.

2. Penyajian Data (Data Display) 


\section{Sindy,Frans.Implementasi Kedisiplinan di SDN Sukorame 2.....}

Penyajian data yang telah di reduksi sebelumnya merupakan data yang relevan dengan penelitian. Data tersebut di sajikan secara deskriptif yaitu berupa hasil wawancara tentang penjabaran kepala sekolah dan guru terkait pendidikan karakter, serta dokumentasi visi misi dan program sekolah yang berkaitan dengan implementasi kedisiplinan.

3. Penarikan Kesimpulan (Conclusion Drawing/Verification)

Data-data yang telah dikemukakan pada penyajian data diinterpretasikan kemudian dianalisis untuk memperoleh kesimpulan.

Pengujian kredibilitas data, dilakukan dengan menggunakan triangulasi dan bahan referensi, Triangulasi yang digunakan peneliti adalah triangulasi teknik dan sumber.

1. Trianggulasi sumber, untuk menguji kredibilitas data dilakukan dengan cara mengecek data yang telah diperoleh melalui beberapa sumber. Peneliti menggali informasi dari kepala sekolah lalu triangulasi, guru serta siswa. Data dari sumbersumber tersebut dideskripsikan, dikategorisasikan, mana yang memiliki pandangan sama, yang berbeda, dan mana yang spesifik.

2. Triangulasi Teknik, untuk menguji kredibilitas data dilakukan dengan cara mengecek data kepada sumber yang sama dengan teknik yang berbeda. Dalam penelitian ini, peneliti mengungkapkan data tentang implementasi kedisiplinan sebagai bekal membentuk pendidikan karakter pada siswa di SDN Sukorame 2 dengan teknik wawancara, lalu dicek dengan observasi, kemudian dengan dokumentasi.

\section{HASIL}

Implementasi kedisiplinan sebagai bekal membentuk pendidikan karakter di SDN Sukorame 2 sebagai berikut:

1. Didalam kelas

Kedisiplinan yang berlaku didalam kelas yaitu siswa harus datang tepat waktu sebelum pelajaran dimulai agar siswa mulai membiasakan diri untuk tidak datang terlambat, melaksanakan tugas piket kelas sesuai jadwal yang sudah disepakati bersama satu kelas, berdoa sebelum pelajaran dimulai dimaksudkan agar siswa setiap melakukan pekerjaan tetap mengutamakan agama dengan berdoa agar semua yang dikerjakan lancar, 
Sindy, Frans.Implementasi Kedisiplinan di SDN Sukorame 2..... mendengarkan dan memperhatikan penjelasan Guru didalam kelas nenbiasakan siswa untuk patuh menerima ilmu yang disampaikan guru didalam kelas, Dilarang meninggalkan kelas pada saat jam pelajaran tanpa seijin guru, Bersikap sopan, santun dan menghargai semua warga sekolah, ikut menjaga 9K (Ketertiban, Kebersihan, Keindahan, Kekeluargaan, Keamanan, Kerindangan, Kesehatan, Keterbukaan) dan dilarang membawa HP. Implementasi Kedisiplin yang berada didalam kelas tersebut tertuang didalam papan tata tertib kelas. Tata tertib di kelas wajib ditaati oleh semua siswa agar siswa menjadi terbiasa dengan disiplin waktu, tugas dan belajar menjadi siswa yang berkarater baik sesuai program sekolah.

\section{Diluar kelas}

Implementasi kedisiplinan yang berlaku diluar kelas yaitu Siswa tidak boleh datang terlambat, memakai seragam sekolah sesuai dengan jadwal yang ditentukan, mengikuti upacara bendera dengan khidmat, siswa saat hari senin memakai seragam merah putih dengan atribut lengkap seperti dasi, topi, ikat pinggang lalu berbaris dihalaman sekolah untuk melaksanakan upacara dan siswa mengikuti tata tertib sekolah yang sudah dituliskan dipapan masing-masing kelas. Saat jam istirahat siswa dibiasakan untuk disiplin menggunakan waktu digunakan untuk membaca buku diperpustakaan agar wawasan siswa bertambah luas siswa dapat membaca buku cerita, pelajaran, dan kamus. Setelah selesai membaca siswa dibiasakan untuk mengembalikkan buku yang diambil ketempat semula. Saat istirahat siswa makan bersama bekal yang dibawa ke sekolah. Selain itu siswa dibiasakan agar menjaga kebersihan sekolah yaitu dengan adanya tugas piket, 2 minggu sekali melaksanakan kerja bakti untuk menjaga kebersihan sekolah. Setiap siswa selesai makan makanan ringan membuang sampah ke tempat sampah yang telah disediakan di Sekolah.

\section{PEMBAHASAN}

SDN Sukorame 2 Kota Kediri yang berlokasi di Jalan Himalaya No.2 telp. (0354) 777878 Kecamatan Mojoroto Kota Kediri. SDN Sukorame 2 memiliki 21 tenaga pengajar dengan kualifikasi minimal S1, 1 tenaga administrasi dan penjaga sekolah. SDN 
Sindy,Frans.Implementasi Kedisiplinan di SDN Sukorame 2.....

Sukorame 2 memiliki fasilitas yang cukup lengkap meliputi ruang kelas, kantor, perpustakaan, ruang kesehatan, koperasi sekolah, mushola, dan ruang rapat.

SDN Sukorame 2 sangat mendukung pengembangan prestasi siswa baik bidang akademik maupun non akademik. Pada SDN Sukorame 2 terdapat 9K yang terdiri atas (Ketertiban, Kebersihan, Keindahan, Kekeluargaan, Keamanan, Kerindangan, Kesehatan, Keterbukaan) untuk menanamkan pendidikan karakter pada siswa seperti implementasi kedisiplinan sebagai bekal membentuk pendidikan karakter pada siswa. Pendidikan karakter merupakan pendidikan yang bertujuan untuk meningkatkan mutu penyelenggaraan dan hasil pendidikan yang mengarah pada pencapaian pembentukan karakter dan akhlak mulai peserta didik secara utuh, terpadu, dan seimbang. SDN Sukorame 2 mempunyai program pembiasaan yang sudah menjadi budaya di sekolah dan dibagi menjadi 2 yaitu di dalam kelas dan di luar kelas.

Disiplin adalah sebuah kata yang sangat dijauhi oleh anak-anak kita di sekolah maupun dirumah.Tentu untuk menumbuhkan kedisiplinan diri diperlukan dari beberapa pihak.Pihak pertama adalah si anak itu sendiri, orang tua, lingkungan (masyarakat) dan lingkungan sekolah manakala si anak tersebut masih dalam proses pendidikan di sekolah. Sekolah adalah tempat yang sangat baik untuk mendisiplinkan anak tentu tidak meninggalkan disiplin yang ditanamkan dari rumah. Rumah adalah tempat yang pertama kali si anak untuk mengenalkan bagaimana anak menjadi displin dalam segala aspek kehidupan. Anak akan mengenal disiplin manakala orang tua sebagai linkungan pertama mengenalkan disiplin dalam segala aktifitasnya dirumah yang kemudian dapat diwujudkan diluar rumah (walaupun diluar rumah akan sangat berbeda kondisinya dan tidak sesuai dengan apa yang diajarkan dirumah). Seorang anak yang dari rumah sudah diajarkan disiplin akan merasa asing jika ada teman sebaya atau lebih tua tetapi tidak disiplin,kan tetapi kalau penanaman karakter cukup baik maka anak akan tetap mempertahankan yang ditanamkan oleh orangtuanya dan ini juga tergantung kondisi masyarakatnya mendukung atau tidak. Menurut Wong dan Wong (2009, hal. 184), peraturan yang spesifik dapat diterapkan apabila siswa mengetahui secara tepat perilaku apa yang dianggap penting seperti halnya tata tertib sekolah. Curwin (2008:72) Pelaksanaan peraturan kelas yang terbaik yaitu ketika mendeskripsikan perilaku secara spesifik. Dalam penelitian ini perilaku yang dianggap penting untuk mendapat perhatian adalah kedisiplinan siswa untuk menaati peraturan di dalam kelas. 


\section{Sindy,Frans.Implementasi Kedisiplinan di SDN Sukorame 2.....}

Disiplin dalam hal ini adalah disiplin diri dari para siswa terhadap peraturan dan waktu. Menurut (Nizar:2010) disiplin diri merupakan sikap patuh kepada waktu dan peraturan yang ada. Dengan disiplin waktu dalam mengikuti kegiatan belajar mengajar, siswa akan belajar mempunyai tanggung jawab terhadap aturan waktu yang ada. Suatu peraturan yang dilaksanakan dengan baik akan membuat seseorang hidup disiplin denga nterbiasa. (Depdiknas:2011) dengan hidup secara disiplin maka individu/seseorang akan dapat meraih tujuan dalam hidupnya dengan sukses. Dengan demikian, pelaksanaan program sekolah dalam pencapaian visi dan misinya untuk mewujudkan mutu lulusan yang mempunyai kompetensi sesuai standar nasional pendidikan akan bisa tercapai apabiladidukung dengan implementasi kedisiplinan yang baik dan semua komponen sekolah yang mempunyai komitmen terhadap kedisiplinan.

Menurut (Yudhawati, 2011). Kedisiplinan siswa tidak bisa dibangun dengan sendirinya, karena kedisiplinan siswa bisa terwujud atas dasar kesadaran dalam diri masing-masing siswa. Perlu adanya peran penting sekolah dalam mewujudkan kedisiplinan siswa agar tercapainya prestasi siswa yang baik pula Oleh sebab itu, peran sekolah untuk mendisiplinkan siswa yaitu dengan membuat aturan-aturan dan tata tertib yang diberlakukan secara tegas dan konsisten. Jika aturan dan tata tertib tersebut diberlakukan secara tegas dan konsisten, maka siswa yang pada awalnya terpaksa dengan aturan dan tata tertib yang ada akan merasa terbiasa mematuhinya. Peraturan dan tata tertib yang diberlakukan secara tegas dan konsisten diharapkan akan meningkatkan kedisiplinan siswa yang berkaitan tentang pendidikan karakter pada anak.

Pendidikan karakter melalui sekolah,tidak semata mata pembelajaran pengetahuan semata, tetapi lebih dari itu,yaitu penanaman moral, nilai-nilai etika, estetika, budi pekerti yang luhur. Dan yang terpenting adalah praktikan setelah informasi tersebut diberikan dan lakukan dengan disiplin olehsetiap elemen sekolah. Di SDN Sukorame 2 Setiap warga sekolah harus displin mematuhi tata tertib yang ada agar semua warga sekolah tidak semena-mena dalam menjalankan tuganya. Seperti halnya siswa, Guru harus mematuhi tata tertib sekolah seperti harus datang tepat waktu, menggunakan seragam sesuai peraturan sekolah tidak menggunakan aksesoris berlebihan saat mengajar dan memberikan materi sesuai dengan apa yang sudah ditetapkan oleh sekolah.

Pelaksanaan pendidikan karakter diperkuat melalui 18 nilai yang ada pada satuan pendidikan yang bersumber dari agama, Pancasila, budaya, dan tujuan pendidikan 
Sindy,Frans.Implementasi Kedisiplinan di SDN Sukorame 2.....

nasional, yaitu: religius, cinta damai, toleransi, disiplin, kerja keras, kreatif, mandiri, demokratis, rasa ingin tahu, semangat kebangsaan, cinta tanah air, menghargai prestasi, bersahabat/ komunikatif, jujur, gemar membaca, peduli lingkungan, peduli sosial, dan tanggung jawab (Kemdiknas, 2011: 8). Dengan pendidikan karakter bisa memicu kecerdasan emosi anak. Kecerdasan emosi menjadi bekal anak dalam menghadapi segala macam tantangan, salah satunya tantangan pada akademik anak. Dengan karakter, anak tidak terbelenggu sifat materialistis, melainkan melalui karakter akan memicu hubungan yang harmonis dengan masyarakat dan sekitarnya. Karakter merupakan kunci keberhasilan manusia (Mustadi, 2011).

\section{SIMPULAN}

Berdasarkan hasil penelitian ditemukan bahwaimplementasi kedisiplinan sebagai bekal membentuk pendidikan karakter pada siswa di SDN Sukorame 2 telah dicurahkan kedalam program sekolah yang meliputi: Siswa hadir 10 menit sebelum pelajaran dimulai, siswa memakai seragam sesuai jadwal, mengikuti upacara benderan dengan khidmat, melaksanakan dan mentaati tata tertib sekolah, melaksanakan tugas piket sesuai jadwal. Kedisiplinan di SDN Sukorame merupakan program pendidikan karakter yang diberikan sebagai bekal anak dalam menghadapi segala macam tantangan, salah satunya tantangan pada akademik anak.

\section{UCAPAN TERIMAKASIH}

Ucapan terimakasih kami tujukan kepada seluruh pihak yang telah membantu terselesaikannya penelitian ini. Peneliti juga menyampaikan terimakasih kepada Universitas Nusantara PGRI Kediri yang telah memberi dukungan untuk kegiatan penelitian ini

\section{DAFTAR RUJUKAN}

Ariananda, Eka S., Hasan Syamsuri, Rakhman maman, 2014. Pengaruh kedisiplinan siswa di sekolah terhadap Prestasi belajar siswa teknik pendingin. Journal of Mechanical Engineering Education, Vol.1, No.2. https://ejournal.upi.edu/index.php/jmee/article/view/3805/2711

Curwin, R. L., Mendler, A. N., \& Mendler, B. D. (2008). Discipline with dignity 3rd Development editioni. Alexandria: Association for Supervision and Curriculum

Depdiknas. 2011. Kedisiplinan adalah Modal kesuksesan. http://www.diknas.go.id/info. 2011. Diakses tanggal 15 April 2020. 
Sindy,Frans.Implementasi Kedisiplinan di SDN Sukorame 2.....

Gunarsa, S. D. (2008). Psikologi Perkembangan Anak dan Remaja. Jakarta: PT. BPK Gunung Mulia. 15 April 2020

Hidayatullah, M.Furqon. 2010. Pendidikan Karakter: Membangun Peradaban Bangsa. Surakarta: Yuma Perkasa.

Kemdiknas. 2011. Panduan Pelaksanaan Pendidikan Karakter. Jakarta: Badan Penelitian dan Pengembangan Pusat Kurikulum dan Perbukuan.

Mustadi, Ali. (2011). Pendidikan Karakter Berwawasan Sosiokultural (Sociocultural Based Character Education) di Sekolah Dasar, Daerah Istimewa Yogyakarta (DIY).

Nizar. 2010. Pengertian Disiplin Diri. http://faridnyzer169.wordpress.com.2010. Diakses tanggal 15 April 2020.

Pelawi, Eimenina Saemara,Dkk. Penetapan Dan Penerapan Peraturan Spesifik Untuk Meningkatkan Kedisiplinan Siswa Kelas VIII SMP ABC Cikarang. A Journal Of Language, Literature, Culture, And Education POLYGLOT Vol. 12 No. 2 April 2016

Tu'u, T. (2004). Peran Disiplin pada Prilaku dan Prestasi Siswa. Jakarta: Grasindo.

Wong, H. K., \& Wong, R. T. (2009). The first days of school. Yogyakarta:Pustaka Pelajar.

Yasin. Fatah. Penumbuhan Kedisiplinan Sebagai Pembentukan Karakter Peserta Didik Di Madrasah. Jurnal el-Hikmah Fakultas Tarbiyah UIN Maliki Malang. 15 April 2020

Yudhawati, R. \& Haryanto, D. (2011). Teori-teori Dasar Psikologi Pendidikan. Jakarta: Prestasi Pusaka. 